LOPEZ MERCHÁN, R., «Mujer inmigrante víctima de violencia de género», REDUR II, diciembre 20I3, págs. 199-229.

ISSN $1695-078 \mathrm{X}$

\title{
MUJER INMIGRANTE VÍCTIMA DE VIOLENCIA DE GÉNERO
}

\author{
Raquel LÓPEZ MERCHÁN \\ LICENCIADA EN DERECHO \\ UNIVERSIDAD NACIONAL DE EDUCACIÓN A DISTANCIA
}

SUMARIO: I. Introducción. II. Mujer inmigrante. III. Legislación en materia de extranjería y violencia de género. III.r. Derecho a la autorización de residencia y trabajo independiente de las mujeres extranjeras reagrupadas por sus cónyuges. III.2. Derecho a la autorización de residencia temporal y trabajo por circunstancias excepcionales de las mujeres extranjeras. III.3. Exención de la situación nacional de empleo. IV. Los derechos de las mujeres víctimas de violencia de género. V. Especial alusión al derecho a la asistencia jurídica gratuita y el derecho a la salud. V.I. Derecho a la tutela judicial efectiva. V.2.D Derecho a la asistencia jurídica gratuita. V.3. Derecho a la salud. VI. Conclusiones y reflexiones.

RESUMEN: Inmigración, mujer y violencia de género es una combinación bastante «explosiva» en cuanto a la reestructuración o el recorte de derechos.

PALABRAS ClAVE: inmigración, mujer, violencia de género, derecho a la asistencia jurídica gratuita, derecho a la salud.

ABSTRACT: Inmigration, woman and gender violence are an explosive mixture related to cut of rights.

KEYWORDS: inmigration, woman, gender violence, free legal aid, health right.

\section{Introducción}

Según el artículo I3 de la Constitución Española, «los extranjeros gozarán en España de las libertades públicas que garantiza el presente Título en los términos que establezcan los tratados y la ley».

Ser persona extranjera significa carecer de la nacionalidad del país que te acoge tras un proceso migratorio.

Los movimientos migratorios siempre han existido en la sociedad, desde que el ser humano obtuvo la facultad de moverse. El desplazamiento de un pueblo a otro, de una ciudad a otra o de un país a otro es un derecho que posee todo ser humano como bien 
aparece recogido en la Declaración Universal de los Derechos Humanos ${ }^{\mathrm{I}}$. La circulación de las personas es una tendencia innata del ser humano, existiendo, como se establece en la Declaración Universal, una libertad de circulación entre los países.

Es por este motivo que las personas viajan a otras ciudades, a otros países en muchos casos por placer, para conocer otros lugares, pero también, lo hacen por motivos económicos. Es decir, buscando un futuro mejor para su vida o para su familia.

La violencia de género no hace distinción de clase social, raza, edad,... sino que cualquier mujer puede ser protagonista de esta macabra película en la que los papeles de víctima y agresor están asignados desde un primer momento: la víctima es la mujer y el agresor es el hombre.

La violencia de género existe desde hace muchos años, pero ha estado oculta tras la cortina de la normalidad, pues según la cultura patriarcal el hombre es el jefe de la familia, de la sociedad y la mujer es un peón que se mueve a su antojo.

La combinación inmigración y violencia de género provoca unas situaciones de vulnerabilidad mayores para las mujeres inmigrantes y unos recortes de derechos, más aún que si estuviéramos hablando de mujeres nacionales víctimas de violencia de género.

Para escribir este artículo se ha tratado de tener una visión bastante multidisciplinar del tema al leer artículos de varias personas estudiosas del tema y al hablar con distintas personas que trabajan en diversas áreas de trabajo, no sólo en el ámbito jurídico. Porque tener una visión multidisciplinar es muy importante para abordar el tema de la violencia de género y luchar contra ella.

\section{Mujer inmigrante}

Las mujeres inmigrantes son un colectivo especialmente vulnerable ${ }^{2}$, lo cual viene provocado por los siguientes factores.

En primer lugar el duelo migratorio, haciendo alusión a la situación psicológica especial que condiciona las percepciones y el comportamiento de gran parte de las mujeres que toman la decisión de migrar.

En segundo lugar el choque cultural. Las sociedades, nacionalidades y las culturas de las que provienen estas mujeres pueden ser muy diferentes a lo que se encuentran cuando llegan a España.

En tercer lugar la carencia de redes sociales naturales en las que poder apoyarse, pues el viaje supone romper con los vínculos familiares y de amistad, lo cual dificulta posibles apoyos. En muchos casos, además, existen dificultades económicas, lingüísticas o administrativas.

\footnotetext{
${ }^{\mathrm{I}}$ El art. I3 de la Declaración Universal de los Derechos Humanos establece que «toda persona tiene derecho a circular libremente y a elegir su residencia en el territorio de un Estado». Del mismo modo, toda persona tiene reconocido el derecho a salir de un país, incluso del suyo propio, y regresar a él.

${ }^{2}$ Por vulnerabilidad podemos entender «la combinación de las diferencias de poder basadas en una estructura en la que el inmigrante se encuentra en un nivel inferior que los nacionales y del conjunto de elementos culturales que lo justifican, tiene por resultado diversos grados de impunidad en caso de violación de los derechos humanos del migrante».
} 
En cuarto lugar la fuerte dependencia de la mujer inmigrante respecto de su pareja. En muchos casos han venido gracias a la reagrupación familiar o no tienen documentación propia o en regla, no tienen ingresos propios, etc. Todo esto contribuye a dificultar la independencia de las mujeres que sufren violencia de género para disponer como quieran de su vida.

El quinto factor es la percepción de las instituciones públicas más como una amenaza que como fuente de protección. Esto es así porque las mujeres inmigrantes sienten una gran desconfianza hacia los cuerpos de seguridad del país. Ésta se puede tornar en miedo a ser expulsadas si ellas se encuentran en situación administrativa irregular y son víctimas de una agresión violenta y su situación administrativa sale a la luz al interponer una denuncia. También existe falta de confianza porque ante la denuncia de su situación, se pueden sentir culpables si su pareja es expulsada o si ven la posibilidad de que sus hijas e hijos les puedan ser arrebatadas/os.

El sexto facto al que hay que hacer mención es al miedo a no ser creída o a que la denuncia de violencia de género pueda afectar al proceso de regularización.

En 2003 Amnistía Internacional (AI) ponía de manifiesto su preocupación porque en el Estado español existiera un trato discriminatorio hacia las mujeres migrantes indocumentadas; pues estas mujeres podían ver mermada la protección frente a las violaciones de los derechos humanos, simplemente por hallarse en una situación de ausencia de documentación.

Esta organización ha detectado una serie de obstáculos que provocan el debilitamiento del acceso a la protección efectiva ante la violencia en el ámbito familiar de las mujeres que se encuentran en situación administrativa irregular.

Marcadas e invisibles. AI recuerda que uno de los derechos básicos que tienen todas las personas migrantes es el de contar con la documentación necesaria para acceder al conjunto básico de derechos, independientemente de su situación administrativa.

Es aconsejable que las personas inmigrantes se inscriban en el padrón municipal del lugar de residencia con independencia de su situación administrativat. Esto es recomendable porque el certificado de empadronamiento es un documento público que acredita su estancia en el país y que «facilitará», en el futuro, la obtención de la documentación para su permanencia en éls. Lo que quizás las personas inmigrantes desconozcan, es que el padrón debe ser renovado cada dos años, pues si no lo hacen causan baja y se interrumpe el tiempo «legal» de estancia en nuestro país.

\footnotetext{
${ }^{3}$ AMNISTÍA INTERNACIONAL, Mujeres invisibles, abusos impunes. Mujeres migrantes indocumentadas en España ante la violencia de género en el ámbito familiar, junio, 2003, pág. 8.

${ }^{4}$ Artículo 6 de la Ley Orgánica 2/2009, de in de diciembre, de reforma de la Ley Orgánica 4/2000, de II de enero, sobre derechos y libertades de los extranjeros en España y su integración social, a partir de ahora NLOEX. Este artículo establece lo siguiente: «(...) 2. Los extranjeros residentes, empadronados en un municipio, tienen todos los derechos establecidos por tal concepto en la legislación de bases de régimen local, pudiendo ser oídos en los asuntos que les afecten de acuerdo con lo que disponga la normativa de aplicación.

3. Los Ayuntamientos incorporarán al padrón a los extranjeros que tengan su domicilio habitual en el municipio y mantendrán actualizada la información relativa a los mismos».

${ }^{5}$ Como dice AI en el mencionado informe «el empadronamiento es el único cauce para visibilizar a las personas que habitan en un determinado municipio, y permitirles con ello el acceso a los derechos fundamentales inherentes a toda persona, con independencia de su situación administrativa».
} 
Regulaciones en materia de extranjería e impactos sobre las decisiones de las migrantes indocumentadas víctimas de violencia de género en el ámbito familiar. Muchas mujeres vienen a España como consecuencia de la reagrupación familiar solicitada por el marido que ya se encuentra aquí. Esto es una forma de explicar la especial vulnerabilidad de las mujeres inmigrantes frente a la violencia de género. Ser reagrupada por su marido o pareja conlleva la falta de autonomía económica, lingüística -en muchos casos-, administrativa,...

Acceso a la asistencia jurídica ${ }^{6}$ y acceso a la red de protección pública ante la violencia de género en el ámbito familiar. Muchas mujeres se encuentran con dificultades para acceder a los centros de emergencia y otros recursos que se destinan a apoyar y proteger a las mujeres víctimas de violencia de género.

Seguimos hablando de los obstáculos con los que se encuentran las mujeres inmigrantes, pero ahora haremos hincapié en aquellas mujeres que sufren situaciones de violencia de género. Cabe preguntarse por qué no rompen con el círculo de violencia, cuáles son los motivos que les impiden romper con la relación?

La realidad psicosocial de las mujeres migrantes. Como hemos dicho, las mujeres han sufrido un fuerte proceso de desarraigo al dejar atrás sus espacios de origen, todo lo conocido, esperando tener una vida mejor. Se produce un choque con la realidad, una frustración de las expectativas y se encuentran ante unas condiciones de precariedad laboral y de vivienda con las que no contaban. Las conductas adquiridas culturalmente no se transforman únicamente porque las condiciones de vida mejoren.

Diferencias culturales y de proyecto migratorio y los papeles. Estar en situación administrativa irregular provoca que la mujer sea objeto de medidas restrictivas que tienen un fuerte impacto en la toma de decisiones ${ }^{8}$.

Tanto el EMUME de la Guardia Civil $^{9}$ como el SAM de la Policía Nacional ${ }^{\text {10 }}$ están autorizados, con la ley en la mano, a poner en conocimiento de la brigada de extranjería la situación de irregularidad de la mujer.

Cuando nos encontramos ante una situación de violencia de género, la condición de estar «sin papeles» (o en situación administrativa irregular) es determinante para el proceso complejo de decidir denunciar a su agresor. Las mujeres inmigrantes valoran diversos factores:

En primer lugar tienen en cuenta su situación administrativa y la situación administrativa de su pareja. Muchas de estas mujeres desean que la justicia les ayude a conseguir que sus parejas cambien. Quieren mantener el vínculo afectivo pero sin violencia. La expulsión como amenaza se valora como factor que inhibe a muchas de estas

\footnotetext{
${ }^{6}$ Sobre este punto hablaremos en un apartado posterior.

${ }^{7}$ GASCÓN SORRIBAS, E. y GRACIA IBÁÑEZ, J., La problemática específica de las mujeres inmigrantes en procesos de violencia familiar de género, Zaragoza, Laboratorio de Sociología Jurídica, Universidad de Zaragoza, págs. 3-6.

${ }^{8}$ AMNISTÍA INTERNACIONAL, cit., pág. Io y ss.

${ }^{9}$ EMUME es el Equipo de Mujer y Menor de la Guardia Civil.

${ }^{\text {ro }}$ El SAM es el Servicio de Atención a la Mujer que posee el Cuerpo de la Policía Nacional.
} 
mujeres a interponer la denuncia o las induce a intentar retirarla, aunque sabemos que eso, procesalmente, no es posible.

En el caso de haber iniciado un proceso de reagrupación de sus hijos mientras la pareja permanecía conviviendo, surgen las dudas de si al dictarse una orden de protección puede suponer una desestimación de su petición de reagrupación familiar en relación a sus hijos.

También tienen muy en cuenta la realidad socioeconómica en la que viven: precariedad laboral, inexistencia de contratos estables, dificultad a la hora de encontrar una vivienda, ausencia de apoyo familiar en España, envío de dinero a su país de origen,...

III. La legislación en materia de extranjería y violencia de género

Con la reforma realizada de la Ley Orgánica 4/2000, de in de enero, sobre derechos y libertades de los extranjeros y de su integración en España ${ }^{\text {II }}$, diversos derechos se reconocieron a las mujeres extranjeras que han sido víctimas de violencia de género.

III.I. Derecho a la autorización de residencia y trabajo independiente de las mujeres extranjeras reagrupadas por su cónyuge (art. I9)

En la mayoría de los casos las mujeres vienen reagrupadas por sus esposos, quienes iniciaron en primer lugar el proceso migratorio. Al ser reagrupadas obtuvieron una autorización de residencia por reagrupación familiar, la cual es siempre dependiente de la de su esposo.

En el caso de ser víctima de violencia de género, estas mujeres pueden obtener una autorización de residencia y trabajo independiente desde el momento en que se hubiese dictado a favor de la mujer una orden de protección o, en su defecto, informe del Ministerio Fiscal que indique la existencia de indicios de violencia de género.

III.2. Derecho a la autorización de residencia temporal y trabajo por circunstancias excepcionales de las mujeres extranjeras (art. 3I bis)

El artículo 3I bis fue añadido por la Ley Orgánica 2/2009 estableciéndose que las mujeres extranjeras que sean víctimas de violencia de género, dando igual la situación administrativa que posean, tendrán garantizados todos los derechos que la Ley Orgánica I/2004 reconozca, al igual que también tendrán derecho a las medidas de protección y seguridad que se establezcan en la legislación que esté vigente.

En el caso de que la mujer que interpone la denuncia por violencia de género se encuentre en situación administrativa irregular, el expediente administrativo sancionador que se incoe por cometer la infracción que aparece regulada en el art. 53.I a) ${ }^{12}$ será suspendido por el instructor hasta que se resuelva el procedimiento penal.

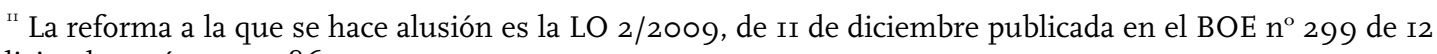
de diciembre, págs. I04986-I05031.

${ }^{12}$ Art. 53: Infracciones graves. I. Son infracciones graves: a) Encontrarse irregularmente en territorio español, por no haber obtenido la prórroga de estancia, carecer de autorización de residencia o tener caducada más de tres meses la mencionada autorización, y siempre que el interesado no hubiera solicitado la renovación de la misma en el plazo previsto reglamentariamente.
} 
En este artículo se regula la posibilidad que tienen las mujeres extranjeras víctimas de violencia de género que se encuentren en situación administrativa irregular de solicitar una autorización de residencia y trabajo por circunstancias excepcionales a partir del mismo momento en que se hubiera dictado una orden de protección a su favor o, en su defecto, informe del Ministerio Fiscal que indique la existencia de indicios de violencia de género. La resolución no se hará efectiva hasta que no se concluya el procedimiento penal.

Una vez concluido el procedimiento penal con sentencia condenatoria se procederá a conceder y notificar a la mujer la concesión de la autorización de residencia temporal y trabajo por circunstancias excepcionales.

Si se concluye el procedimiento penal sin que se pueda llegar a la conclusión de la existencia de una situación de violencia de género, la autorización de residencia temporal y trabajo por circunstancias excepcionales será denegada.

\section{III.3. Exención de la situación nacional de empleo (art. 40)}

Se regulan los supuestos específicos estableciéndose que no se tendrá en cuenta la situación nacional de empleo, entre otros casos, cuando el contrato vaya dirigido a aquellos extranjeros que hayan obtenido la autorización de residencia por circunstancias excepcionales en aquellos supuestos que establezca el Reglamento y en todo caso, cuando se trate de víctimas de violencia de género o de trata de seres humanos.

El Reglamento ${ }^{\mathrm{r}}$ que desarrolla la NLOEX regula la residencia temporal por circunstancias excepcionales en su título V. El capítulo segundo se encarga de la residencia temporal y trabajo por circunstancias excepcionales de las mujeres extranjeras víctimas de violencia de género.

Artículo I3I: Denuncia a favor de una mujer extranjera víctima de violencia de género. En el caso de que la mujer extranjera que ha interpuesto una denuncia por ser víctima de violencia de género se encuentre en España en situación irregular, el procedimiento sancionador que se pueda iniciar debido a este motivo quedará suspendido hasta que se termine el proceso penal.

Artículo I32: Inicio del procedimiento relativo a la residencia temporal y trabajo de la mujer extranjera víctima de violencia de género. La mujer que se encuentre en la situación descrita en el artículo anterior podrá solicitar, ella misma o su representante, una autorización de residencia y trabajo por circunstancias excepcionales ante la Oficina de Extranjería que corresponda desde el mismo momento en que se haya dictado a su favor una orden de protección o el Ministerio Fiscal haya emitido un informe donde establezca que existen indicios suficientes de violencia de género.

En el caso de que tenga a su cargo menores de edad podrá solicitar en todo momento una autorización de residencia por circunstancias excepcionales o de residencia y

\footnotetext{
${ }^{13}$ Real Decreto 557/20II, de 30 de abril, por el que se aprueba el Reglamento de la Ley Orgánica 4/2000, sobre derechos y libertades de los extranjeros en España y su integración social, tras su reforma por Ley Orgánica 2/2009. Texto aprobado por el Parlamento el I5 de abril de 2011 tras casi un año de retraso, pues debería haber sido publicado en junio de 20I0, como muy tarde, ya que era cuando se cumplían los 6 meses otorgados para su redacción. BOE n ${ }^{\circ}$ IO3 de 30 de abril de 201 I, págs. 4382I-44006.
} 
trabajo para los mayores de i6 años para ellos, siempre y cuando dichos menores se encuentren en España en el momento de la interposición de la denuncia.

En el tercer párrafo de este artículo se detalla la documentación que debe presentar la mujer junto con la solicitud: copia del pasaporte completo o documento de viaje en vigor de la mujer y de los menores a su cargo, o el documento por el cual se le otorgue la representación legal de dichos menores y la copia de la orden de protección o del informe emitido por el Ministerio Fiscal.

Artículo I33: Autorización provisional de residencia temporal y trabajo de la mujer extranjera víctima de violencia de género. Una vez presentada la solicitud de la autorización de residencia y trabajo el Delegado o Subdelegado del Gobierno otorgará una autorización provisional a favor de la mujer extranjera víctima de violencia de género y de sus hijos menores con la condición de la existencia de una orden de protección o del informe del Ministerio Fiscal.

Esta autorización de residencia y trabajo conlleva la posibilidad de trabajar para la mujer, teniendo el mismo alcance la autorización que se conceda a los hijos mayores de i6 años.

La vigencia de esta autorización estará condicionada a la concesión o denegación de la autorización definitiva.

Desde que se conceda la autorización, la titular de la misma tiene el plazo de un mes para solicitar la Tarjeta de Identidad de Extranjero, la cual tendrá una vigencia de un año. En esta tarjeta aparecerá que la titular está autorizada para residir y trabajar, pero no constará que la mujer es víctima de violencia de género ni que la autorización tiene carácter temporal.

Artículo 134: Finalización del procedimiento relativo a la residencia temporal y trabajo de la mujer extranjera víctima de violencia de género. Una vez concluido el proceso penal, la autoridad judicial lo pondrá en conocimiento tanto de la Oficina de Extranjería como de la Comisaría de Policía. Esto es así porque, concluido el procedimiento con sentencia condenatoria o resolución judicial de la que se deduzca que la mujer ha sido víctima de violencia de género, si se ha solicitado una autorización de residencia y trabajo, deberá ser concedida en el plazo de 20 días desde que en la Oficina de Extranjeros conste la sentencia. Esta autorización tendrá una duración de 5 años, sin perjuicio de la posibilidad de que pueda acceder a la residencia de larga de duración. Desde la concesión, en el plazo de un mes, la titular de la autorización debe solicitar la Tarjeta de Identidad de Extranjero, en la cual constará la autorización para residir y trabajar, pero no su condición de víctima de violencia de género.

Pero si no se solicitó la autorización de residencia y trabajo, el Ministerio Fiscal informará a la mujer de la posibilidad que tiene de solicitar la autorización provisional de residencia y trabajo para ella y también autorización de residencia o de residencia temporal y trabajo a favor de sus hijos menores.

En el caso de la concesión de la autorización de residencia y trabajo por circunstancias excepcionales, se archivará el procedimiento sancionador que pudiera existir en contra de la mujer extranjera víctima de violencia de género. 
Cuando la sentencia no sea condenatoria o de la resolución judicial no se deduzca que la mujer es víctima de violencia de género, si se ha solicitado autorización de residencia y trabajo: se deniega la misma y de las solicitadas para los menores o incapaces, automáticamente se pierde la eficacia de la autorización provisional; se inicia o se continúa el procedimiento sancionador en materia de extranjería junto con su tramitación y resolución.

En materia de extranjería y violencia de género, el Gobierno dictó el Plan de Atención y Prevención de la violencia de género en población extranjera inmigrante que tiene una duración de cuatro años (2009-2012). El objetivo es crear condiciones adecuadas para abordar el problema de violencia de género atendiendo a las circunstancias específicas de la población extranjera con el objeto de mejorar la atención y prevención desde una perspectiva global. Para que esto sea posible se toman como referencia la corrección de dos de los factores fundamentales que son el sesgo cultural por medio de la información, la sensibilización y la concienciación y los apoyos externos mediante la atención, asesoramiento y las ayudas que se encarguen de reforzar los derechos de las mujeres.

Actualmente la mujer víctima de violencia de género tiene un hueco en la regulación del asilo y el refugio.

En I967 se dictó la Declaración sobre el Asilo Territorial por la Asamblea General de las Naciones Unidas, recogiéndose una serie de principios elementales que estaban relacionados con el asilo ${ }^{\mathrm{I}}$ : el Estado es el encargado de asilar y debe apreciar la validez de los motivos invocados; el otorgamiento de asilo es un acto pacífico y humanitario; la condición de asilado no se otorgará en aquellos supuestos de crímenes de guerra, contra la paz o contra la humanidad; el solicitante de asilo no puede ser objeto de rechazo en frontera, tampoco puede ser devuelto o expulsado a un Estado en el que corra el riesgo de ser perseguido nuevamente; la solidaridad internacional debe intervenir para aliviar las cargas de los Estados cuando el otorgamiento de asilo les conlleve ciertas dificultades; la persona sujeta a la condición de asilado no puede realizar actividades que vayan en contra de los principios elementales de la Carta de las Naciones Unidas.

El artículo 3 de la Convención contra la tortura y otros tratos o penas crueles, inhumanos o degradantes ${ }^{15}$ impide la devolución al país de origen o al país del que proceda el extranjero, aun cuando no se le haya considerado refugiado de acuerdo con el Convenio de Ginebra: ...ningún Estado Parte procederá a la expulsión, devolución o extradición de una persona a otro Estado cuando haya razones fundadas para creer que estaría en peligro de ser sometida a tortura.

La Comisión Europea creó un proyecto bajo el nombre de Pacto Europeo sobre Inmigración y Asilo ${ }^{16}$, que fue refrendado el 15 y i6 de octubre de 2008 por el Consejo Europeo, mediante el cual los Jefes de Estado y de Gobierno expresan el compromiso

\footnotetext{
${ }^{\mathrm{I} 4}$ KAHALE CARRILLO, D.T., El derecho de asilo frente a la violencia de género, Madrid, Editorial Universitaria Ramón Areces, 2010, pág. 76.

${ }^{15}$ La Convención contra la tortura y otros tratos o penas crueles, inhumanos o degradantes fue adoptada y abierta a la firma, ratificación y adhesión por la Asamblea General en su resolución 39/46, de io de diciembre de I984; entrando en vigor el 26 de junio de I987.

${ }^{16}$ El Pacto Europeo sobre Inmigración y Asilo data del 24 de septiembre de 2008 , el cual no ha sido publicado en el Diario Oficial.
} 
político de la Unión Europea y de sus Estados miembros, comprometiéndoles con sus ciudadanos y con los terceros Estados de cara a una política común en materia de migraciones $^{\text {17 }}$.

La Ley 5/1984, de 26 de marzo es la encargada de la regulación del derecho de asilo y de la condición de refugiado ${ }^{18}$ tras la aparición de estas figuras en el art. 13.4 de la Constitución Española ${ }^{\mathrm{r}}$.

Diez años después se dicta la Ley 9/ı994, de I9 de mayo, de modificación de la Ley 5/1984, de 26 de marzo, reguladora del derecho de asilo y de la condición de refugiado. Los aspectos fundamentales que diferencian a ambas leyes son: supresión de la dualidad entre asilo y refugio, estableciendo dos estatutos diferenciados; desaparición de la discrecionalidad del Estado al consagrar el derecho de asilo, pues se concederá este derecho a quien se le reconozca la condición de refugiado de acuerdo con lo dispuesto en la Convención de Ginebra; establecimiento de una fase previa de inadmisión a trámite, la cual permite rechazar las solicitudes que se consideren manifiestamente infundadas o aquellas cuya tramitación no corresponde al Estado Español; creación de un procedimiento en frontera; aplicación de la legislación general de extranjería en lo referente al asilo por razones humanitarias; otorgamiento del carácter suspensivo al informe del ACNUR.

En I995 se dicta el Real Decreto 203/1995, de io de febrero, por el cual se aprueba el Reglamento de aplicación de la Ley 5/1984, de 6 de marzo, reguladora del derecho de asilo y de la condición de refugiado, modificada por la Ley 9/1994, de I9 de mayo, dictado para completar a la ley.

El 2009 fue un año cargado de novedades legislativas al citarse la reforma de la ley de extranjería y la Ley I2/2009, de 30 de octubre, reguladora del derecho de asilo y de la protección subsidiaria ${ }^{20}$. Las novedades que trae esta ley se pueden resumir en del siguiente modo: equiparación del estatuto de refugiado y la protección subsidiaria elevándolos a protección internacional; distinción entre asilo y extranjería; recogida de las características de género, orientación sexual y edad como causas que pueden dar lugar al

\footnotetext{
${ }^{17}$ Los compromisos a los que se hace referencia en este documento son los siguientes:

I. Organizar la inmigración legal, pero teniendo en cuenta las prioridades, necesidades y capacidades de acogida determinadas por cada Estado miembro y promover la integración.

2. Luchar contra la inmigración irregular, asegurando el retorno de los extranjeros en situación no regular a su país de origen o a uno de tránsito.

3. Reforzar la eficacia de los controles fronterizos.

4. Construir una Europa de asilo.

5. Establecer una asociación global con los países de origen y de tránsito, de modo que favorezca las sinergias entre las migraciones y el desarrollo.

${ }^{18}$ El asilo se concibe como una institución que depende en exclusiva de la soberanía del Estado. Por el contrario, el refugio es una figura internacional que adopta España por medio de la Convención de Ginebra de I95I.

${ }^{19}$ El art. I3.4 de nuestra Constitución Española establece que «la ley establecerá los términos en que los ciudadanos de otros países y los apátridas podrán gozar del derecho de asilo en España».

${ }^{20}$ Esta ley es obra de la obligación de transponer tres instrumentos normativos europeos: Directiva 2004/83/CE del Consejo de 29 de abril, Directiva 2005/85/CE del Consejo de I de diciembre y la Directiva 2003/86/CE del Consejo de 22 de septiembre.

Amnistía Internacional se encarga de realizar una crítica a esta ley, pues considera que restringe el hecho de poder acceder al derecho de asilo, el cual es un derecho humano universal. La norma se encarga de limitar aún más el acceso de las víctimas de violaciones de derechos humanos a solicitar protección internacional. Supone una reducción sustancial de las garantías de las víctimas, pues no acoge a los europeos comunitarios como sujetos solicitantes de asilo. Esta limitación es contraria a la Convención de Ginebra, la cual debe ser la piedra angular de todo sistema de asilo.
} 
reconocimiento del estatuto de refugiado por pertenecer a un determinado grupo social; reforzamiento de las garantías inherentes al procedimiento de obtención de protección internacional; regulación del reasentamiento ${ }^{21}$; desarrollo de la exclusión, revocación y el cese de la protección internacional; alusión a la posibilidad de presentar la solicitud, junto con los sitios que son clásicos para ello, en los Centros de Internamiento para Extranjeros; inclusión de las causas que determinan el cese o la exclusión del disfrute del derecho de asilo; señalamiento de los motivos de persecución; el efecto de la concesión del estatuto de refugiado o de protección subsidiaria da acceso a la educación, a la asistencia sanitaria, a la vivienda, a la asistencia social y servicios sociales, así como a los derechos reconocidos por la legislación aplicable a las personas que son víctimas de la violencia de género, teniendo también acceso a la Seguridad Social y a los programas de integración en las mismas condiciones que los nacionales del país de recepción; no se aplica a su cónyuge o a aquella persona con la que esté ligada por una relación de afectividad análoga y convivencia el derecho de asilo o la protección subsidiaria de la persona refugiada o beneficiaria de la protección subsidiaria, cuando la persona haya sufrido o tenido fundados temores de llegar a sufrir persecución por violencia de género por parte del cónyuge o conviviente.

El objeto de la Ley i2/2009 es establecer los términos en que las personas nacionales de países no comunitarios y las apátridas podrán gozar en España de la protección internacional constituida por el derecho de asilo y la protección subsidiaria, así como el contenido de dicha protección internacional.

El art. 2 da una definición de lo que es el derecho de asilo diciendo que es la protección dispensada a los nacionales no comunitarios o a los apátridas a quienes se les reconozca la condición de refugiado en los términos que se definen en el artículo 3 de la Ley y en la Convención sobre el Estatuto de los Refugiados.

Según la Real Academia Española el refugiado es la persona que, a consecuencia de guerras, revoluciones o persecuciones políticas, se ve obligada a buscar refugio fuera de su país.

La Convención de Ginebra y su Protocolo de Nueva York ${ }^{22}$ dicen que el refugiado es toda persona que «debido a fundados temores de ser perseguida por motivos de raza, religión, nacionalidad, pertenencia a determinado grupo social $u$ opiniones políticas, se encuentre fuera del país de su nacionalidad y no pueda, o a causa de fundados temores, no quiera acogerse a la protección de tal país; o que careciendo de nacionalidad y hallándose fuera del país donde antes tuviera su residencia habitual, no pueda, o a causa de dichos temores, no quiera regresar a él».

\footnotetext{
${ }^{21}$ Se podrá reasentar por medio de la fijación de un cupo anual y con la intervención del ACNUR, a un número de refugiados establecidos en países limítrofes al de su origen y que pese a ser refugiados, no tienen garantizada la no devolución a éste porque corre peligro.

${ }^{22}$ La Convención sobre el Estatuto de los Refugiados se adoptó en Ginebra, Suiza, el 28 de julio de I95I por la Conferencia de Plenipotenciarios sobre el Estatuto de los Refugiados y de los Apátridas (Naciones Unidas) convocada por la Asamblea General en su resolución 429 (V), del I4 de diciembre de i950. Su entrada en vigor se produjo el 22 de abril de I954, de conformidad con el artículo 43 Serie de Tratados de Naciones Unidas, $\mathrm{n}^{\circ}$ 2545, vol. I89, pág. 137, disponible en el sitio web:

http://www.acnur.org/t3/fileadmin/scripts/doc.php?file=biblioteca/pdf/0005 (fecha de consulta: I5 de febrero de 2013).
} 
La Ley de Asilo establece lo mismo que estos textos internacionales pero, además, recoge el motivo de género u orientación sexual como motivo para obtener la condición de refugiado.

La Convención establece una serie de requisitos generales necesarios para obtener la condición de refugiado: el sujeto debe ser extranjero o apátrida y encontrarse fuera del país de origen o residencia habitual, deben existir fundados temores de ser perseguido si regresa a su país, las causas del temor fundado de persecución deben concretarse en motivos de raza, religión, nacionalidad, pertenencia a un determinado grupo social u opiniones políticas y de género, debe existir una situación de desprotección objetiva al no poder acogerse a la protección de su país o subjetiva que no quiera ampararse a ella a causa de los fundados temores.

El art. 3 de la Ley dice que esta condición será reconocida a toda persona que «debido a fundados temores de ser perseguida por motivos de raza, religión, nacionalidad, opiniones políticas, pertenencia a determinado grupo social, de género u orientación sexual, se encuentra fuera del país de su nacionalidad y no puede o, a causa de dichos temores, no quiere acogerse a la protección de tal país, o al apátrida que, careciendo de nacionalidad y hallándose fuera del país donde antes tuviera su residencia habitual, por los mismos motivos no puede o, a causa de dichos temores, no quiere regresar a él, y no esté incurso en alguna de las causas de exclusión del artículo 8 o de las causas de denegación o revocación del artículo 9».

Como novedad aparece la protección subsidiaria (art. 4) que es aquella protección que se otorga a las personas de otros países y a los apátridas que, no habiendo reunido los requisitos para obtener el asilo o ser reconocidas como refugiadas, pero respecto de los cuales se den motivos fundados para creer que si regresan a su país de origen en el caso de los nacionales o, al de su anterior residencia habitual en el caso de los apátridas, se enfrentarían a un riesgo real de sufrir alguno de los daños que se prevén en el art. io de la ley, y que no pueden o, a causa de dicho riesgo, no quieren, acogerse a la protección del país de que se trate, siempre que no concurra alguno de los supuestos mencionados en los artículos iı y I2.

Las mujeres extranjeras víctimas de género deben reunir las condiciones generales para poder obtener el derecho a la protección, por cualquiera de los Estados parte de los convenios internacionales, y para que les sea reconocido el estatuto de refugiada. Cuando se les sea reconocido, tendrán el derecho a residir en el territorio español y a desarrollar cualquier actividad laboral, profesional y mercantil. Cuando una extranjera entra en territorio español y le conceden dicha condición tendrá una autorización de permanencia provisional mientras se sustancia el expediente. En el caso de que no traiga ninguna documentación, el Ministerio del Interior acordará la residencia obligatoria a la interesada hasta que se resuelva definitivamente su expediente.

La condición de refugiada será reconocida a las mujeres víctimas de violencia de género que, debido a fundados temores de ser perseguidas por motivos de pertenencia a determinado grupo social, de género u orientación sexual, se encuentran fuera del país que les otorga la nacionalidad y no pueden o, a causa de dichos temores, no quieren acogerse a la protección de dicho país. También se concede a la mujer apátrida que, careciendo de 
nacionalidad y hallándose fuera del país en donde tuviera antes su residencia habitual, por los mismos motivos no puede o, a causa de dichos temores, no quiere regresar a él.

Para el reconocimiento del derecho de asilo se precisa que los fundados temores de las mujeres a ser objeto de persecución estén basados en actos de persecución considerados graves y que revistan la forma de actos de violencia física o psíquica, incluidos los actos de violencia sexual.

En función de las circunstancias imperantes en el país de origen se incluye a las personas que huyen de sus países de origen debido a fundados temores de sufrir persecución por motivos de género.

Los requisitos específicos para que una víctima de violencia de género pueda acceder a la condición de refugiada son los siguientes:

Existencia de un temor fundado de ser perseguida ${ }^{23}$. Hay que estar al caso concreto que se estudia para valorar y determinar cuándo se puede establecer que existe un temor fundado de persecución. En este requisito se engloba el elemento objetivo (deber de demostrar que el temor es fundado) y el elemento subjetivo (encargado de estimar los factores tipo de personalidad y credibilidad de quien solicita).

Nexo causal. Para que se otorgue el estatuto de persona refugiada hay que demostrar que la persona solicitante teme ser perseguida por motivos de raza, religión, nacionalidad, pertenencia a un grupo social determinado $u$ opiniones políticas.

En los casos de violencia de género, cesaría la condición de refugiada para la víctima de violencia de género cuando se produzca una de estas dos circunstancias: cuando el maltratador ya no vive en el país de origen de la persona refugiada y en el caso de que el país de origen de la mujer que ha sido víctima de violencia de género adopte una legislación o se implantan medidas efectivas que van destinadas a prevenir y/o penalizar la violencia de género.

\section{Los derechos de las mujeres extranjeras víctimas de violencia de género}

Todas las personas, como ya sabemos, poseen una serie de derechos denominados humanos. Estos derechos son enumerados y reconocidos internacionalmente para después, ser trasladados a las legislaciones nacionales de los Estados que los han ratificado.

Las mujeres extranjeras que han sido o que son víctimas de violencia de género tienen reconocidos unos derechos en la NLOEX que ya hemos enumerado en un apartado anterior. Pero como, aparte de ser extranjeras, son mujeres y víctimas de esta clase de violencia, la $\mathrm{LOVG}^{24}$ les reconoce una serie de derechos específicos.

\footnotetext{
${ }^{23}$ Gracias a las Directrices sobre protección internacional de la persecución por motivos de género en el contexto del artículo iA (2) de la Convención de i95i sobre el Estatuto de los Refugiados y/o su Protocolo de I967 del ACNUR, se enumeran los supuestos de temor fundado de persecución por motivos de género por los cuales la persona solicitante de asilo obtendría la condición de persona refugiada: juzgar una ley como persecutoria en sí y por sí misma, práctica persecutoria, pena o sanción, discriminación equivalente a la persecución, persecución motivada por la orientación sexual, la trata de personas para la prostitución o explotación sexual forzosa como una forma de persecución y agentes de persecución.

${ }^{24}$ LOVG hace alusión a la Ley Orgánica I/2004, de 28 de diciembre, de Medidas de Protección Integral contra la Violencia de Género.
} 
Derecho a la información (art. I8 LOVG): derecho a recibir toda la información y el asesoramiento necesario sobre las medidas de protección, los derechos, ayudas y los recursos de atención, emergencia, apoyo y recuperación integral y el modo de acceder a ellos.

Derecho a la asistencia social (art. I9 LOVG): las mujeres y sus hijas/os menores tienen derecho a unos servicios sociales que comprende la atención, la emergencia, el apoyo, la acogida y la recuperación integral. Por medio de estos derechos se hace posible que las mujeres reciban asesoramiento sobre las actuaciones y los derechos, conozcan los servicios a los que puede dirigirse, acedan a los distintos recursos de alojamiento y puedan recuperar su salud física y/o psicológica y, al mismo tiempo, logren su formación, inserción o reinserción laboral, recibiendo el apoyo psico-social a lo largo del itinerario de recuperación integral.

Derecho a la asistencia jurídica inmediata. Derecho a la asistencia jurídica gratuita (art. 20 LOVG): la ley reconoce a las mujeres víctimas de violencia de género la asistencia jurídica gratuita en todos los procedimientos relacionados con la situación de violencia. Junto con la defensa y la representación gratuitas también se incluyen otras prestaciones: asesoramiento y orientación gratuitos previos al proceso, inserción gratuita de anuncios o edictos en periódicos oficiales, la exención del pago de depósitos necesarios para interponer recursos, la asistencia pericial gratuita y la obtención gratuita (o con una reducción del $80 \%)$ de los derechos arancelarios de los documentos notariales.

Derechos laborales y de Seguridad Social (art. 2I LOVG) y existencia de un programa específico de empleo (art. 22 LOVG y RD I9I7/2008, de 2I de noviembre, por el que se aprueba el programa de inserción sociolaboral para mujeres víctimas de violencia de género): aquellas mujeres víctimas de violencia de género que se encuentren inscritas como demandantes de empleo en el INEN podrán ser beneficiarias del programa de inserción socio-laboral, el cual incluye una serie de medidas ${ }^{25}$.

Renta activa de inserción (RAI) ${ }^{26}$ : ayuda económica que se reconoce a las personas desempleadas incluidas en el «programa de renta activa de reinserción», por medio del cual se llevan a cabo actuaciones encaminadas a incrementar las oportunidades de inserción en el mercado laboral.

${ }^{25}$ Las medidas que incluye el programa específico de empleo son: itinerario de inserción socio-laboral individualizado, programa formativo específico para favorecer la inserción socio-laboral por cuenta ajena, incentivos para favorecer el inicio de una nueva actividad por cuenta propia, incentivos para las empresas que contraten a víctimas de violencia de género, incentivos para facilitar la movilidad geográfica, incentivos para compensar las diferencias salariales, convenios con empresas para facilitar la contratación de mujeres víctimas de violencia de género y su movilidad geográfica.

${ }^{26}$ RD I369/2006, de 24 de noviembre, por el que se regula la Renta Activa de Inserción para desempleados con especiales necesidades económicas y dificultad para encontrar empleo. BOE $\mathrm{n}^{\circ} 290$ de 5 de diciembre de 2006, págs. 42717-4272I.

Para que la mujer pueda ser incluida en la RAI y ser beneficiaria de la ayuda económica, la mujer víctima de violencia de género debe cumplir una serie de requisitos: acreditar la condición de víctima de violencia de género por medio de una orden de protección judicial o resolución judicial donde se acuerde la medida cautelar penal de protección; ser demandante de empleo; no tener derecho a las prestaciones o subsidios por desempleo; carecer de rentas propias.

La percepción de esta ayuda es incompatible con la ayuda económica regulada en el art. 27 de la ley integral. 
Derechos económicos (Capítulo IV LOVG): para poder ser beneficiaria de esta ayuda (art. 27 de la LOVG) deben cumplir unos requisitos: carecer de rentas, especiales dificultades para obtener empleo y acreditar la condición de víctima de violencia de género.

Tramitación urgente del procedimiento de reconocimiento de anticipos del Fondo de Garantía del Pago de Alimentos ${ }^{27}$ : las personas beneficiarias serán las hijas y los hijos menores de edad titulares de un derecho de alimentos judicialmente reconocido e impagado.

Derecho al reconocimiento de la pensión de viudedad en supuestos de violencia de género $^{28}$ y prioridad en el acceso a viviendas protegidas y residencia públicas para mayores (art. 28 LOVG).

Derecho a la escolarización inmediata de sus hijos/as en caso de cambio de residencia como consecuencia de la violencia de género (art. 5 LOVG).

También se les reconoce los derechos que las leyes establecen para las víctimas de delito:

Derecho a formular la denuncia: con la denuncia se inicia el procedimiento judicial ante el Juzgado de Violencia sobre la Mujer para aclarar los hechos y sancionar a los culpables.

Derecho a solicitar una orden de protección: las medidas de protección que la autoridad judicial puede acordar a favor de la mujer víctima de violencia de género y, en el caso de que existan, de sus hijas e hijos, pueden ser de carácter penal y civil.

Derecho a ser parte en el procedimiento penal (ofrecimiento de acciones) y derecho a la restitución de la cosa, reparación del daño e indemnización del perjuicio causado: en la sentencia condenatoria se sancionará al culpable y se fijarán las responsabilidades civiles que el culpable debe abonar a la víctima. La víctima tiene la posibilidad de reservarse su derecho a ejercer la acción civil en un procedimiento distinto ante los juzgados civiles. De este modo, en el procedimiento penal no se ejercitará la acción civil. Pero la víctima también puede renunciar a cualquier reclamación que le pudiera corresponder.

Derecho a recibir información sobre las actuaciones judiciales aunque la víctima no ejerza su derecho a intervenir en el proceso penal, debe ser informada de su papel en el proceso y del alcance, desarrollo y la marcha del procedimiento.

Derecho a la protección de la dignidad e intimidad de la víctima en el marco de los procedimientos relacionados con la violencia de género y a acceder a las ayudas económicas previstas para las víctimas de delitos violentos y contra la libertad sexual.

${ }^{27}$ RD I6r8/2007, de 7 de diciembre, sobre organización y funcionamiento del Fondo de Garantía del Pago de Alimentos. BOE $\mathrm{n}^{\circ} 299$ de I4 de diciembre de 2007, págs. 5I37I-51376.

${ }^{28}$ Art. I74.2 Texto Refundido de la Ley General de la Seguridad Social (RDL r/ı994, de 20 de junio, BOE ${ }^{\circ}$ I54 de 29 de junio de I994, págs. 20658-20708). 


\section{Especial alusión a la asistencia jurídica gratuita y el derecho a la salud}

\section{V.I. Derecho a la tutela judicial efectiva}

El art. $24 \mathrm{CE}^{29}$ es el encargado de reconocer este derecho. Debido a la situación que ocupa dentro del texto legislativo más importante, está encuadrado dentro del título dedicado a los derechos fundamentales que posee la ciudadanía, hallándonos ante un derecho fundamental que asiste a todo sujeto de Derecho.

El ordenamiento jurídico lo pone a disposición de las personas para que puedan defender sus bienes y sus derechos. Por medio de él podemos acceder de modo libre al Poder Judicial usando un proceso con todas las garantías y permitiendo el acceso a todas las instancias posibles.

Es un derecho complejo, pues tenemos un derecho principal que está compuesto por otros derechos que lo complementan. Todos ellos, en su conjunto, se relacionan con la protección judicial.

Derecho a la jurisdicción, estamos haciendo alusión a que la titularidad de este derecho corresponde a todas las personas: físicas (tanto nacionales como extranjeras, residentes «legales» e «ilegales» y comunitarios), jurídicas, privadas y públicas. Consiste en provocar que una actividad jurisdiccional desemboque en una decisión judicial. Se encuentra íntimamente unido con la necesidad existente de que las sentencias estén motivadas.

Derecho a un proceso sin dilaciones indebidas se está haciendo referencia a que la parte se debe encontrar ante un proceso con todas las garantías, lo cual implica que el Juez debe ser imparcial. El proceso debe ser respetuoso con los principios de contradicción, igualdad de armas, siendo dispositivo en el proceso civil y acusatorio en el proceso penal.

Una sentencia debe ser congruente. Se incluye el derecho a obtener una sentencia de fondo. Una sentencia debe estar motivada, razonada y fundada en Derecho. La motivación de la sentencia debe ser una conclusión de la argumentación del Juzgado o del Tribunal, la cual se debe ajustar al tema que se ha planteado en el litigio. Si la sentencia es arbitraria, se está negando radicalmente la tutela judicial. Cuando hablamos de motivada, hacemos alusión a que debe estar basada en los hechos, debe ser motivada o fundada en los fundamentos de Derecho y debe ser congruente, es decir, coherente con las pretensiones de las partes.

Como dice el Tribunal Constitucional «la tutela judicial efectiva ha de impedir que las sentencias y los derechos en ellas reconocidos se conviertan en meras declaraciones de intenciones sin alcance práctico ni efectividad alguna». Lo que está queriendo decir aquí el

\footnotetext{
${ }_{29}$ Art. 24 CE: «I. Todas las personas tienen derecho a obtener la tutela judicial efectiva de los jueces y tribunales en el ejercicio de sus derechos e intereses legítimos, sin que, en ningún caso, pueda producirse indefensión.

2. Asimismo, todos tienen derecho al Juez ordinario predeterminado por la ley, a la defensa y a la asistencia de letrado, a ser informado de la acusación formulada contra ellos, a un proceso público sin dilaciones indebidas y con todas las garantías, a utilizar los medios de prueba pertinentes para su defensa, a no declarar contra sí mismos, a no confesarse culpables y a la presunción de inocencia.

La Ley regulará los casos en que, por razón de parentesco o de secreto profesional, no se estará obligado a declarar sobre hechos presuntamente delictivos».
} 
Tribunal es que de nada sirve la declaración que se realiza en la sentencia si después ésta no se lleva a la práctica y no se ejecuta.

La principal función del derecho a la tutela judicial efectiva es que cualquier persona puede y debe ser amparada en el ejercicio de sus pretensiones ante la justicia. La condición que es indispensable cumplir es que las pretensiones deben ser ejercidas de modo pacífico.

En sentencias del Tribunal Constitucional (STC 89/1985, STC 135/1986 y STC 54/1997) se habla del contenido y la interpretación del mencionado artículo y el derecho que en él se comprende. En todas ellas se establece que si se viola o se lesiona el derecho a la tutela judicial efectiva, se produce una indefensión de la parte. La defensa es un derecho muy importante de nuestro ordenamiento y toda persona tiene derecho a una defensa justa, quedando en manos de la parte acusadora la carga de la prueba.

En la Sentencia del Tribunal Constitucional (STC) 89/1985, el Ministerio Fiscal hace alusión a que los dos puntos que componen el artículo se encuentran relacionados, pero necesitan ser tratados de modo diferenciado: el primer apartado hace referencia al medio de acceder al proceso judicial y el segundo alude a las garantías procesales, entre las que se encuentra los medios de prueba oportunos.

En las sentencias se alude al hecho de que si la resolución se encuentra fundada en Derecho es poco probable que ésta pueda violar el derecho fundamental al que nos estamos refiriendo.

En relación con el apartado 2 del artículo $24 \mathrm{CE}$, si las pruebas pertinentes y adecuadas al caso han sido propuestas en tiempo y forma, pero su ejecución ha sido denegada de modo arbitrario, se está violando el derecho fundamental que asiste a toda persona como sujeto de Derecho. Dentro de las garantías de protección que tiene todo individuo que litigue, existe el derecho a ser oído y a disponer de todas las posibilidades de oposición y defensa en juicio. Si esto no se da, se produce una indefensión que es susceptible de amparo.

Se puede comprobar que estamos ante un derecho con un contenido muy amplio o complejo. Se describe un derecho general o principal (derecho a la tutela judicial efectiva), el cual está compuesto por otros derechos, principios y garantías que lo complementan (la presunción de inocencia, el derecho de acceso a la justicia, el derecho a un proceso sin dilaciones indebidas,...). Todos ellos están interrelacionados entre sí dando forma a un derecho autónomo con contenido propio y complejo.

\section{V.2. Derecho a la asistencia jurídica gratuita ${ }^{30}$}

El derecho a la asistencia jurídica gratuita se regula en el art. II9 CE: «La justicia será gratuita cuando así lo disponga la ley y, en todo caso, respecto de quienes acrediten insuficiencia de recursos para litigar». Este derecho se encuentra íntimamente relacionado con el derecho recogido en el art. 24.I CE que se encarga de regular la tutela judicial efectiva.

${ }^{30}$ LÓPEZ MERCHÁN. R., «La asistencia jurídica gratuita a las mujeres víctimas de violencia de género», REDUR, $n^{\circ}$ 9, Diciembre 20II, págs. 357-373, disponible en el sitio web:

http://www.unirioja.es/dptos/dd/redur/numerog/lopez.pdf (fecha de consulta: 20 de mayo de 20I3). 
Por lo tanto, podemos comprobar que el derecho a la tutela judicial efectiva y el derecho a la asistencia jurídica gratuita son dos derechos que se encuentran muy relacionados; pues en muchos casos, si ves vulnerado un derecho y no tienes recursos económicos suficientes para afrontar los gastos de un proceso judicial, puedes acudir a la asistencia jurídica gratuita y acceder a otro derecho fundamental reconocido por la Constitución (el derecho de acceso a la jurisdicción).

El art. I de la Ley I/I996, de io de enero ${ }^{31}$, nos indica el objeto de la misma estableciendo que es determinar el contenido de la asistencia jurídica gratuita al que se refiere el artículo 119 de la Constitución y regula el procedimiento para su reconocimiento y efectividad (PERDICES MAÑAS 2006, 5I y ss.), recogiendo, además, unos mecanismos para facilitar el acceso a la Justicia en pie de igualdad a las partes procesales (arts. I4 y 24 Constitución Española).

En el art. $2^{32}$ de esta ley se establece quiénes tendrán derecho a esta asistencia, siempre que acrediten que tienen insuficiencia de recursos para litigar, precepto modificado tras la sentencia del Tribunal Constitucional 95/2003 de 22 de mayo. Con anterioridad a la mencionada sentencia, se otorgaba este derecho a los extranjeros que residieran legalmente en España. Esta expresión fue declarada inconstitucional, pero no así la expresión «residieran». Por ello, el derecho a la asistencia jurídica gratuita se extendió a todos los extranjeros que residan en España sin tener en cuenta su situación administrativa.

La solicitud de la asistencia jurídica consiste en una declaración de voluntad, que efectúa el titular de un derecho o interés legítimo, de querer actuar en defensa del mismo (administrativa o judicialmente), en el plazo determinado legalmente, con el concurso de una asistencia técnica (abogado/a y procurador/a), incluso en aquellos supuestos en los que quepa autodefensa, y con cuantos más beneficios le puedan corresponder conforme a la Ley I/96 y normativa complementaria, sin que ello le suponga un quebranto económico que le lleve a desatender las necesidades de sustento propio y las de su familia (especialmente en los supuestos en que se acredite la carencia de recursos para litigar).

Los requisitos básicos necesarios que deben cumplirse para solicitar esta asistencia jurídica son regulados en el art. 3 Ley I/I996: los recursos e ingresos económicos, computados anualmente por todos los conceptos y por unidad familiar, no pueden superar el doble del IPREM; si supera el doble del IPREM, pero no el cuádruple, la Comisión de Asistencia Jurídica Gratuita atenderá a las circunstancias de la familia de la solicitante, el número de hijos/as o familiares a su cargo, el estado de salud, minusvalía, obligaciones económicas, etc.; la persona solicitante litiga en defensa de derechos e intereses propios.

La LOVG se encarga de modificar el apartado 5 del artículo 3 de la Ley i/ı996, de io de enero, de Asistencia Jurídica Gratuita disponiendo que se excluye la necesidad de acreditar previamente la carencia de recursos económicos por parte de las víctimas de violencia de género y establece la inmediatez en la prestación de la asistencia jurídica gratuita.

\footnotetext{
${ }^{31}$ BOE $n^{\circ}$ II de I2 de enero de I996, págs. 793-803.

${ }^{32}$ En el apartado I de este artículo se alude a las personas que tendrán derecho a la asistencia jurídica gratuita: «los ciudadanos españoles, los nacionales de los demás Estados miembros de la Unión Europea y los extranjeros que se encuentren en España, cuando acrediten insuficiencia de recursos para litigar».
} 
El art. 23.I LECv ${ }^{33}$ recoge el principio general por el cual las partes comparecerán en el proceso civil preceptivamente por medio de procurador/a legalmente habilitado/a para actuar en el tribunal que conozca del juicio. En el párrafo 2 se enumeran los supuestos en los cuales no es necesaria la presencia de procurador/a, añadiendo algunos supuestos que se contienen en las leyes especiales ${ }^{34}$.

La asistencia de letrado/a también aparece regulada en la Ley de Enjuiciamiento Civil, en concreto en el art. 3I:

«I. Los litigantes serán dirigidos por abogados habilitados para ejercer su profesión en el tribunal que conozca del asunto. No podrá proveerse a ninguna solicitud que no lleve la firma de abogado.

2. Exceptuándose solamente:

I $^{\circ}$ Los juicios verbales cuya cuantía no exceda de 900 y la petición inicial de los procedimientos monitorios, conforme a lo previsto en esta Ley.

$2^{\circ}$. Los escritos que tengan por objeto personarse en juicio, solicitar medidas urgentes con anterioridad al juicio o pedir la suspensión urgente de vistas o actuaciones. Cuando la suspensión de vistas o actuaciones que se pretenda se funde en causas que se refieran especialmente al abogado también deberá éste firmar el escrito, si fuera posible».

Normalmente, cuando la mujer víctima de violencia de género interpone una denuncia contra su agresor, está iniciando un proceso penal contra él. En éste, no es preceptivo que acuda representada de abogado/a al inicio, pero sí en los juicios de faltas. Por tanto, la mujer víctima de violencia de género está en todo su derecho de solicitar la asistencia letrada para que la acompañe en todo el proceso judicial penal.

El inicio de un proceso judicial o administrativo que tiene como causa directa o indirecta una situación de violencia de género, conlleva la designación de un/a abogado/a de oficio dentro del turno especializado en la defensa de las víctimas de violencia de género que tenga el Colegio de Abogados correspondiente. Este/a profesional debe informar a la mujer del derecho que tiene a solicitar la asistencia jurídica gratuita $\mathrm{y}$, al mismo tiempo, advertirla de que si este derecho no se le reconoce, deberá abonar los honorarios que se hayan generado.

En los casos de violencia de género no es necesario acreditar la insuficiencia de recursos económicos, pero una vez presentada la solicitud, se tiene un plazo de 5 días para aportar toda la documentación necesaria, a sabiendas de que si no se hace la solicitud será archivada.

\footnotetext{
${ }^{33}$ Ley I/2000, de 7 de enero, de Enjuiciamiento Civil. BOE $n^{\circ} 7$ de 8 de enero de 2000, págs-575-728.

${ }^{34}$ Los supuestos a los que se hace alusión son:

$I^{\circ}$. Juicios verbales cuya cuantía no exceda de 900 .

$2^{\circ}$. Petición inicial en los procesos monitorios.

$3^{\circ}$. En los juicios universales, cuando se limite la comparecencia a la presentación de títulos de crédito o derechos, o para concurrir a Juntas.

$4^{\circ}$. En aquellos incidentes relativos a impugnación de resoluciones en materia de asistencia jurídica gratuita y cuando se soliciten medidas urgentes con anterioridad al juicio.
} 
Centrándonos en las mujeres inmigrantes que son víctimas de violencia de género, nos encontramos ante un colectivo más vulnerable que las mujeres nacionales en general ${ }^{35}$.

La LOVG habla del derecho a la asistencia jurídica gratuita en el art. 20: «las mujeres víctimas de violencia de género que acrediten insuficiencia de recursos para litigar, en los términos establecidos en la Ley Orgánica I/I996, de ıo de enero, de Asistencia Jurídica Gratuita, tienen derecho a la asistencia y representación gratuitas por Abogado y Procurador en todos los procesos y procedimientos administrativos que tengan causa directa o indirecta en la violencia padecida.(...) En todo caso, se garantizará la defensa jurídica, gratuita y especializada de forma inmediata a todas las víctimas de violencia de género que la soliciten, sin perjuicio de que si no se les reconoce con posterioridad el derecho a la asistencia jurídica gratuita, éstas deberán abonar al abogado los honorarios devengados por su intervención».

La mujer inmigrante que tiene sus papeles en regla, es decir, que posee una autorización de residencia o de residencia y trabajo, se encuentra con las mismas dificultades con las que se puede encontrar una mujer española que solicita este derecho: dificultad para presentar los papeles solicitados, miedo ante la incertidumbre de lo que sucederá hasta el momento del inicio del proceso, durante éste y cuando acabe, incertidumbre por el futuro a corto, medio y largo plazo, miedo por sus hijos/as si los tiene,... No se puede olvidar que la justicia transmite desasosiego por lo desconocido.

El mayor obstáculo al ejercicio tanto del derecho a la asistencia jurídica gratuita como, en consecuencia, al derecho a la tutela judicial efectiva, aparece cuando se trata de una mujer inmigrante que no posee ningún tipo de autorización para permanecer en España de modo legal la que se decide a acudir a los Juzgados a interponer una denuncia por malos tratos y solicitar un/a abogado/a de oficio. El problema surge porque desde que la mujer entrega la solicitud, los trámites se inician, pero se sabe de antemano que este derecho no será concedido ante la falta de documentación que acredite la insuficiencia de recursos para litigar. En mi más humilde opinión, más que por la falta de documentación acreditativa de la escasez o insuficiencia de recursos económicos para litigar, la solicitud es rechazada de antemano porque la mujer no presenta la autorización de residencia y trabajo o de residencia únicamente, y, al no presentar esta autorización, el resto de documentación exigida no se puede presentar.

Con este rechazo, sin entrar a valorar el resto de documentación que se puede acompañar, se está produciendo una situación de discriminación y de vulneración del derecho que tiene toda persona a acceder a la jurisdicción para defender los derechos que le han sido violados.

\footnotetext{
${ }^{35}$ Los motivos por los cuales las mujeres inmigrantes son un colectivo más vulnerable podrían ser la circunstancia de no encontrarse en su país de origen, y no tener una red de apoyo a la que acudir para desahogarse y contar lo que está sucediendo, el duelo migratorio requiere un tiempo para desaparecer, el idioma, en muchas ocasiones, también es un impedimento (sobre todo si son mujeres que vienen de países árabes, de Europa del Este, etc.). Muchas de estas mujeres no tienen ingresos económicos propios o sus ingresos vienen de lo denominado «economía sumergida». Todas estas causas, y otras muchas más, son las causantes de que las mujeres inmigrantes sean un grupo social vulnerable.
} 
Si no se concede este derecho a la asistencia jurídica gratuita se está privando a la persona de la posibilidad de acceder a dos derechos recogidos en nuestro texto constitucional: la justicia gratuita del art. II9 CE y la tutela judicial efectiva del art. 24.I CE.

En un primer momento, antes de la reforma realizada tras el dictamen de la sentencia del Tribunal Constitucional 95/2003, los extranjeros sin residencia legal tenían acceso a la asistencia jurídica gratuita para los procedimientos penales y el contenciosoadministrativo sobre el derecho de asilo. Tras esta sentencia que declara inconstitucional el término «legalmente», pero no el término «que residan», todo extranjero residente en España tiene derecho a esta asistencia jurídica gratuita para poder defenderse en cualquier ámbito jurídico. En consecuencia, la mujer inmigrante «sin papeles» que acredite su residencia en España tiene derecho a la concesión de esta asistencia jurídica gratuita con los requisitos que se exigen en la ley.

Muchas de estas mujeres vienen reagrupadas por sus parejas, quienes, como consecuencia de sus pensamientos machistas y retrógrados, se hacen cargo de la custodia de toda su documentación sin permitirle el acceso a ella. Por tanto, quien se hace cargo de la renovación de la documentación, no es la mujer, sino su pareja. Aquí se ve claramente la situación de vulnerabilidad: fuerte dependencia, no sólo emocional, de la mujer hacia su pareja y el miedo ante el cumplimiento de las amenazas de dejarla sin su situación legal.

La mujer, cuando se decide a interponer la denuncia, podrá presentar el pasaporte con el sello de entrada en nuestro país, ante la ausencia de cualquier otra documentación que acredite que su residencia en España es legal, podrá presentar su alta en el padrón municipal mediante la solicitud del empadronamiento (si se produjo), podrá presentar toda clase de documentación que se encargue de acreditar que no dispone de medios económicos suficientes (ni insuficientes) para poder pagar a un/a abogado/a y procurador/a que le represente en el largo proceso judicial, pues carece de una autorización que le permita encontrar trabajo. Podrá presentar un informe redactado por la asociación, ONG que le asista, que le dé cobijo mientras toda la situación se «normaliza» (si es que puede normalizarse en algún momento), pero seguro que esta clase de documentos la Comisión de la Asistencia Jurídica Gratuita no la tendría en cuenta a la hora de valorar los recursos económicos de que dispone la mujer extranjera.

El artículo 22 de la LO 2/2009, recoge este derecho para las personas extranjeras, estableciendo que lo tendrán aquellos extranjeros que se hallen en España para cualquier jurisdicción en las mismas condiciones que los españoles cuando carezcan de recursos económicos: derecho a asistencia letrada y asistencia de intérprete.

Pues bien, este derecho no se lleva a cabo o no se ejercita en el caso de las mujeres extranjeras víctimas de violencia de género que se encuentran en situación administrativa irregular, pues cuando, después de toda la situación vivida y una vez decididas a interponer la denuncia por violencia de género contra su pareja o esposo, se encuentran con que no les es concedido el derecho a la asistencia jurídica gratuita por falta de documentación.

Consultado el Colegio de Abogados de la ciudad de Salamanca ${ }^{36}$, la documentación exigida a la hora de solicitar la asistencia jurídica gratuita es la siguiente: fotocopia del NIF,

\footnotetext{
${ }^{36} \mathrm{http}: / /$ www.icasal.com/ciudadano/ventanilla_unica?seccion=solicitud_de_justicia_gratuita (fecha de consulta: I6 de mayo de 2013).
} 
TIE en vigor, pasaporte en vigor; declaración impositiva de la unidad familiar; certificado de la administración tributaria de no haber presentado declaración si no otorga el consentimiento para que la comisión y el colegio de abogados obtengan directamente de la Administración Tributaria la acreditación; certificado catastral; si se alegan cargas sobre el inmueble, nota simple del registro de la propiedad; certificado de los centros de trabajo y de las altas y bajas de la Seguridad Social; certificado de la empresa acreditativo de los ingresos brutos mensuales; certificado del servicio público de empleo estatal donde conste la percepción de ayuda por desempleo y el período; certificado de cobro de pensiones públicas.

Si nos preguntamos cuáles de estos documentos puede presentar la mujer extranjera víctima de violencia de género en situación administrativa irregular, podemos responder que ninguno, pues para la Administración esta mujer no se encuentra en España. Quizás podría presentar el pasaporte donde se puede comprobar el sello de entrada en nuestro país; pero el resto de documentos son de difícil adquisición.

Entonces, ¿qué ocurre? ¿No tiene derecho a la concesión de la asistencia jurídica gratuita para poder proteger su interés jurídico vulnerado? ¿Qué más pruebas que éstas para acreditar la carencia de recursos económicos para pagar a un abogado/a y procurador/a propio elegido/a por ella misma?

Posiblemente lo único que obre en su poder sea el pasaporte y se puede solicitar un certificado de empadronamiento que acredite desde cuándo se encuentra en España o, al menos, en esa localidad, siempre y cuando, en algún momento supo que podía acceder a este trámite aunque no tuviese la autorización de residencia o la autorización de residencia y trabajo.

Me consta que a estas mujeres les es rechazada la solicitud de asistencia jurídica gratuita por falta de documentación, cuando esa documentación no se presenta porque se carece de ella o, mejor dicho, porque aunque se solicitase los resultados serían negativos, pues para la Seguridad Social, por ejemplo, esa mujer no existiría.

Nos encontramos ante una vulneración flagrante del derecho a la tutela judicial efectiva al que debe tener acceso toda persona. Con esta vulneración se está privando a la mujer de acceder a la justicia y poder denunciar el delito del que ha sido víctima, pues no posee recursos económicos con los que poder pagar a un/a letrado/a y procurador/a que necesita para iniciar el proceso penal.

\section{V.3. Derecho a la salud}

La salud, o el derecho a la salud, se encuentra regulado en distintos textos normativos internacionales, siendo reconocido como un derecho humano o un derecho fundamental y básico que corresponde a toda persona. Los textos internacionales encargados de la regulación de la salud, reconocen el derecho a la asistencia médica sin discriminación para todas las personas ${ }^{37}$. Como todo derecho humano, debe ser garantizado

\footnotetext{
${ }^{37}$ MÉDICOS DEL MUNDO, «Argumentario: la reforma sanitaria y las personas inmigrantes», disponible en el sitio web:

http://www.easp.es/es/system/files/Argumentario\%2oMdM\%2oReforma\%2osanitaria\%2oe\%2oinmigrantes.p df (fecha de consulta: 22 de mayo de 20I3).
} 
y protegido por los Estados. Obligación que han asumido todos los Estados miembros de la UE.

Los acuerdos internacionales que reconocen el derecho a la salud son: la constitución de la OMS (22 de julio de I946), la Declaración Universal de los Derechos Humanos (I948) y Pacto Internacional de Derechos Económicos, Sociales y Culturales (i6 de diciembre de 1966$)^{39}$.

Antes de seguir avanzando con el tema del derecho a la salud, hay que analizar el art. I del Real Decreto-Ley donde aparecen distintas medidas relacionadas con la asistencia sanitaria ${ }^{40}$.

En cuanto al derecho a la asistencia: «La asistencia sanitaria en España, (...), se garantizará a aquellas personas que ostenten la condición de asegurado».

Los requisitos de la persona asegurada ${ }^{4 \mathrm{~T}}$ son: ser persona trabajadora por cuenta ajena o por cuenta propia, afiliada a la Seguridad Social y en situación de alta o asimilada al alta, ostentar la condición de pensionista del Sistema de Seguridad Social, ser persona perceptora de cualquier otra prestación periódica de la Seguridad Social, incluidas la prestación y el subsidio por desempleo, haber agotado la prestación o el subsidio por desempleo y figurar inscrita en la oficina correspondiente como persona demandante de empleo.

Las personas beneficiarias de la persona asegurada serán aquellas «siempre que residan en España, el cónyuge o persona con análoga relación de afectividad, que deberá acreditar la inscripción oficial correspondiente, el ex cónyuge a cargo del asegurado, así como los descendientes a cargo del mismo que sean menores de 26 años o que tengan una discapacidad en grado igual o superior al 65\%».

Las personas extranjeras serán aquellos «extranjeros no registrados ni autorizados como residentes en España recibirán asistencia sanitaria: de urgencia por enfermedad grave o accidente, cualquier que sea su causa, hasta la situación de alta médica, de asistencia al embarazo, parto y postparto y los menores de i8 años en mismas condiciones que los españoles».

Otras posibles personas aseguradas son «las personas de nacionalidad española o de algún Estado miembro de la Unión Europea, del Espacio Económico Europeo o de Suiza

\footnotetext{
${ }^{38}$ El art. 25 DUDH establece que: «I.Toda personas tiene derecho a un nivel de vida que le asegure, así como a su familia, la salud y el bienestar, y en especial la alimentación, el vestido, la vivienda, la asistencia médica y los servicios sociales necesarios; tiene asimismo derecho a los seguros en caso de desempleo, enfermedad, invalidez, viudez, vejez y otros casos de pérdida de sus medios de subsistencia por circunstancias independientes de su voluntad».

${ }^{39}$ El art. I2 PIDESC dice: «Derecho al más alto nivel de salud. Establece la obligación de adoptar medidas para reducir la mortinatalidad y la mortalidad infantil; asegurar el sano desarrollo de los niños; mejorar la higiene del trabajo y del medio ambiente; prevenir y tratar enfermedades epidémicas, endémicas y profesionales, así como asegurar la asistencia médica a todos».

${ }^{40}$ ASOCIACIÓ SALUD Y FAMILIA, «Impacto de la reforma de la asistencia sanitaria en España sobre la cobertura pública y universal», Barcelona, 3 de mayo de 20I2, págs. 4-7. Disponible en el sitio web: http://www.saludyfamilia.es/sites/default/files/Impacto\%2oreforma\%2osanitaria\%2oen\%20Esp\%2oReal\%20 Decreto\%20I6-20I2_cast.pdf (fecha de consulta: 22 de mayo de 20I3).

${ }^{4 \mathrm{r}}$ El Real Decreto-Ley trae de nuevo el concepto de asegurado, enlazando el acceso a la protección de la salud con la vinculación de la ciudadanía con la Seguridad Social.
} 
que residan en España y los extranjeros titulares de una autorización de residencia en territorio español, podrán ostentar la condición de asegurado siempre que acrediten que no superan el límite de ingresos determinado reglamentariamente».

Como consecuencia de esta exposición podemos comprobar que existen unos colectivos que quedan excluidos de la cobertura de la salud pública. Éstos son los ciudadanos/as españoles/as mayores de 26 años residentes en España que nunca han estado en situación de alta o asimilada al alta en el Sistema de Seguridad Social, los ciudadanos/as de países miembros de la Unión Europea, del Espacio Económico Europeo o de Suiza que carezcan de autorización de residencia en España, debiendo demostrar los medios económicos y el seguro privado de salud, y/o no pueden acreditar su situación de paro involuntario ${ }^{42}$ y las personas extranjeras procedentes de países terceros no comunitarios $^{43}$ que carezcan de autorización de residencia en España ${ }^{44}$.

No podemos olvidar que los distintos organismos han expuesto, en relación con los grupos de población excluidos de este derecho, que esta exclusión supone un riesgo para la salud y la vida del grupo afectado y de toda la población residente. La exclusión de estas personas puede generar importantes problemas de salud pública y de saturación de los servicios de urgencias ${ }^{45}$.

Las medidas afectan a unos derechos básicos ${ }^{46}$ : de garantías jurídicas (art. 9.3 CE) relacionado con la irretroactividad de las disposiciones restrictivas sobre derechos individuales, a la dignidad de la persona (art. IO.I CE), de las personas extranjeras (art. I3 $\mathrm{CE}$ ), a la intimidad (art. I8.4 CE) y a la protección a la salud (art. 43.I CE)

Por medio de la reforma se transmite el mensaje de que son las ONG's las encargadas de asegurar la cobertura sanitaria de las personas que han sido excluidas de la misma, lo cual significa que el Estado deja de lado la obligación de proteger la salud de las personas.

Centrándonos en el caso de las personas inmigrantes en situación administrativa irregular (donde podemos incluir a las mujeres inmigrantes víctimas de violencia de género en esta situación administrativa), podemos distinguir dos situaciones:

\footnotetext{
${ }^{42}$ La ciudadanía española y la de países miembros de la UE, del Espacio Económico Europeo o de Suiza que se excluyan de la cobertura sanitaria pública podrían usar unos mecanismos de reentrada en la condición de asegurado debiendo acreditar una situación económica de precariedad.

${ }^{43}$ Para las personas extranjeras procedentes de terceros países no comunitarios excluidos de la cobertura de la sanidad pública, la reforma no prevé ningún mecanismo de reentrada en la condición de asegurado. La única vía sería la de intentar obtener el permiso de residencia en España.

${ }^{44}$ Dentro de las personas extranjeras procedentes de terceros países no comunitarios que no tengan autorización de residencia se incluyen a:

I. Personas extranjeras mayores de I8 años en situación administrativa irregular y no empadronadas.

2. Personas extranjeras mayores de I 8 años empadronadas y actualmente con tarjeta sanitaria que carecen de permiso de residencia en España.

3. Personas extranjeras mayores de i8 años actualmente con tarjeta sanitaria a las que les será denegada la segunda tarjeta de residencia a causa de haber agotado las prestaciones por desempleo y encontrarse en paro de larga duración (irregularidad sobrevenida).

4. Personas extranjeras mayores de i8 años, especialmente mujeres amas de casa reagrupadas, actualmente con tarjeta sanitaria que verán cancelada su tarjeta de residencia en el momento en que se denegada la de su cónyuge (irregularidad sobrevenida).

${ }^{45} \mathrm{http}$ ://www.enfermeriasoria.com/docs/descargas_alberca/Asistencia_a_inmigrantes._Coleg._Enfermeras_ de_Alicante.pdf (fecha de consulta: 22 de mayo de 20I3)

${ }^{46}$ ASSOCIACIÓ SALUD Y FAMILIA, cit., págs. I3-I4.
} 
Las personas inmigrantes irregulares que disfrutaban del derecho a la protección sanitaria hasta el día 3I de agosto de 20I2. Nos encontramos ante una situación sobrevenida que puede decirse que vulnera el principio del art. 9.3 CE.

Las personas inmigrantes irregulares que puedan llegar a España en una fecha posterior a la expuesta.

Hasta la aprobación del Real Decreto-ley I6/20I2, de 20 de abril, de medidas urgentes para garantizar la sostenibilidad del Sistema Nacional de Salud y mejorar la calidad y seguridad de sus prestaciones ${ }^{47}$, las personas extranjeras sin residencia legal, pero que estuvieran empadronadas en el municipio de residencia habitual, podían acceder a la asistencia sanitaria básica. Tras el dictamen de este Real Decreto-ley, las personas extranjeras deben demostrar su residencia legal en España para poder acceder a la sanidad pública. Y, como casos excepcionales, pueden acceder a la salud pública las mujeres extranjeras en situación irregular que se encuentren embarazadas, así como los menores y aquellos casos considerados de urgencia.

En relación con las personas extranjeras, esta norma modifica el art. I2 LOEX $^{4^{8}}$, el cual establece que las personas extranjeras tendrán derecho a la asistencia sanitaria según los términos que se prevean en la legislación vigente relacionada con esta materia. También se añade el art. 3 ter Ley $\mathrm{I} 6 / 2003^{49}$ estableciendo en qué casos las personas extranjeras que no residan de modo legal en el territorio español recibirán asistencia sanitaria ${ }^{50}$.

Se dice también que aquellas personas extranjeras residentes en situación administrativa irregular dejarían de ser beneficiarias de la tarjeta sanitaria a partir del i de septiembre de 2012, lo cual supone volver a la situación existente con anterioridad a la LOEX de 2000.

Desde el punto de vista jurídico no se puede admitir un Real Decreto-Ley que se encargue de derogar o modificar artículos de una norma superior como es la Ley de Extranjería.

${ }^{47}$ BOE n ${ }^{\circ} 98$ de 24 de abril de 20I2, págs. 31278-31312.

${ }^{48}$ El art. I2 LOEX, en su redacción según la LO 2/2009, establece:

«I. Los extranjeros que se encuentren en España, inscritos en el padrón del municipio en el que tengan su domicilio habitual, tienen derecho a la asistencia sanitaria en las mismas condiciones que los españoles.

2. Los extranjeros que se encuentren en España tienen derecho a la asistencia sanitaria pública de urgencia por enfermedad grave o accidente, cualquiera que sea su causa, y a la continuidad de dicha atención hasta la situación de alta médica.

3. Los extranjeros menores de dieciocho años que se encuentren en España tienen derecho a la asistencia sanitaria en las mismas condiciones que los españoles.

4. Las extranjeras embarazadas que se encuentren en España tienen derecho a la asistencia sanitaria durante el embarazo, el parto y el postparto».

${ }^{49} \mathrm{El}$ art. 3 ter Ley $\mathrm{6} 6 / 2003$ establece que las personas extranjeras que no se hallen registradas ni autorizadas como residentes en España sólo recibirán la asistencia sanitaria si se encuentran en alguno de estos tres casos:

a) Urgencia por enfermedad grave o accidente hasta que se produzca el alta médica.

b) Asistencia al embarazo, parto y postparto.

c) Las personas extranjeras menores de i8 años recibirán la asistencia sanitaria en las mismas condiciones que las personas españolas.

${ }^{50} \mathrm{http} / /$ www.enfermeriasoria.com/docs/descargas_alberca/Asistencia_a_inmigrantes._Coleg._Enfermeras_ de_Alicante.pdf (fecha de consulta: 22 de mayo de 20I3) 
Actualmente la condición de la residencia legal para obtener la categoría de persona asegurada es excluyente, lo cual obliga a la persona inmigrante a acudir a las medidas recogidas en el art. 3.5 Ley I6/2003 para poder acceder a los servicios públicos de salud por medio del pago de la contraprestación correspondiente o de una cuota que se deriva de la suscripción de un convenio especial.

Como consecuencia de estas dificultades, se podrá producir una exclusión del sistema nacional de sanidad de un gran número de personas inmigrantes: personas extranjeras que se encuentren en situación irregular actualmente y no estén empadronados, personas extranjeras que tengan tarjeta sanitaria al estar empadronados pero que no posean un permiso de residencia, personas extranjeras que cuenten con la tarjeta sanitaria pero que les será denegada la segunda tarjeta al haber agotado las prestaciones por desempleo y encontrarse en paro de larga duración (provocando una situación de irregularidad sobrevenida) y personas extranjeras, en especial las mujeres que desempeñan la labor de amas de casa y que han sido reagrupadas, con tarjeta sanitaria que será cancelada cuando ésta les sea denegada a sus cónyuges debido a una irregularidad sobrevenida.

La reforma sanitaria realizada por el Gobierno español por medio del Real DecretoLey I6/20I2, de 20 de abril, de medidas urgentes para garantizar la sostenibilidad del Sistema Nacional de Salud y mejorar la calidad y seguridad de sus prestaciones, va en contra del derecho a la salud que corresponde a todas las personas. Conlleva un cambio de tendencia en la protección de la salud de las personas extranjeras no comunitarias en España, pues se debe demostrar que se es residente, es decir, que se posee una autorización de residencia. Se encarga de romper el modelo legal que se encontraba vigente hasta el momento, el cual optaba por reconocer el acceso a la protección sanitaria básica a las personas extranjeras sin residencia legal, pero que se encontrasen empadronados en el municipio de residencia habitual.

Hablamos de los derechos que nuestro ordenamiento jurídico reconoce a las personas extranjeras, en concreto, que el derecho a la salud es un derecho humano que posee toda persona por el mero hecho de ser persona. Pero todos los derechos que tienen reconocidas las personas españolas no les corresponden a las personas extranjeras. Es por ello que los derechos de las personas extranjeras se clasifican en tres grupos: derechos que corresponden por igual a españoles y extranjeros, cuya regulación debe ser idéntica para ambos, derechos que no pertenecen a las personas extranjeras y derechos cuya titularidad comparten personas nacionales y extranjeras pero el ejercicio se condiciona a lo establecido por los Tratados y las leyes.

Dentro de esta clasificación, la protección a la salud, regulada en el art. $43 \mathrm{CE}^{51}$, está englobada dentro de los derechos que las personas extranjeras tienen en plenitud de igualdad que las personas españolas. Esto es así porque la protección a la salud se encuentra íntimamente vinculada con la dignidad humana y los derechos inviolables que le son inherentes (art. IO.I CE). La dignidad es consecuencia del derecho a la vida y a la integridad física y moral. Pero a pesar de esto, el derecho a la protección a la salud se encuentra

\footnotetext{
${ }^{51}$ Art. 43 CE: «I.Se reconoce el derecho a la protección de la salud. 2. Compete a los poderes públicos organizar y tutelar la salud pública a través de medidas preventivas y de las prestaciones y servicios necesarios. La Ley establecerá los derechos y deberes de todos al respecto. 3. Los poderes públicos fomentarán la educación sanitaria, la educación física y el deporte. Asimismo, facilitarán la adecuada utilización del ocio».
} 
incluido en el Capítulo III del Título I como un principio que sólo será aplicable según lo que dispongan las leyes ${ }^{52}$.

Nos encontramos ante un derecho prestacional. El legislador debe sopesar en todo momento y en todo caso el alcance de la acción de protección del sistema en función de las situaciones de necesidad que existan y de los medios financieros de que se dispongan.

El contenido del art. I2 LOEX está referido a la asistencia sanitaria que debe prestar el Sistema Nacional de Salud y no al derecho a la asistencia sanitaria del Sistema de la Seguridad Social. Esto es así porque la LOEX prevé una doble configuración del derecho a la asistencia sanitaria de las personas extranjeras: en primer lugar, la prestación del sistema de Seguridad Social para la población extranjera que desempeña una actividad profesional (art. I4 LOEX) y, en segundo lugar, la medida de protección aplicable a las personas extranjeras en general y que está vinculada con el sistema nacional de salud (art. I2 LOEX) ${ }^{53}$.

Esta diferenciación viene motivada porque las personas extranjeras residentes de forma legal en España y que trabajan por cuenta ajena o por cuenta propia se encuentran encuadradas en el sistema, beneficiándose de su acción protectora y contando con la asistencia sanitaria que se recoge en el art. 38.I a) TRLGSS. En el caso de personas extranjeras que realicen trabajos sin tener una autorización de trabajo y residencia, se benefician de la acción protectora por medio del art. 36.5 LOEX ${ }^{54}$. El art. I2 LOEX se refiere al derecho a la protección de la salud correspondiente a las personas extranjeras, no hace alusión a que tengan autorización de residencia y trabajo o no.

La reforma sanitaria ha modificado los requisitos que las personas extranjeras deben acreditar para poder obtener la asistencia sanitaria. Es por ello que si quieren acceder al Sistema público de Salud, en igualdad de condiciones que las personas españolas, las personas que no son ciudadanas de la Unión Europea y sus familiares (personas nacionales de terceros países) deberán demostrar que son residentes legales en España, para ello deberán tener en vigor una autorización de residencia.

Las personas que no tengan la condición de asegurado o de persona beneficiaria podrán obtener la prestación de asistencia sanitaria por medio del pago de la correspondiente contraprestación que se deriva de la suscripción de un convenio especial (art. 3.5 Ley I6/2003).

Se comprueba que el legislador ha decidido optar por tres niveles de cobertura para las personas extranjeras que se hallen en España de modo irregular: los dos primeros niveles están relacionados con la edad y la situación biológica de la mujer, el tercer nivel

\footnotetext{
${ }^{52}$ FERNÁNDEZ BERNAT, J.A., «Asistencia sanitaria e inmigración irregular», págs. 4-5, disponible en el sitio web: http://www.ces.gva.es/pdf/trabajos/revista67/artı.pdf (fecha de consulta: I9 de mayo de 2013)

${ }^{53}$ FERNÁNDEZ BERNAT, J.A., cit., págs. 6-7.

${ }^{54}$ Art. 36.5 LOEX: «La carencia de la autorización de residencia y trabajo, sin perjuicio de las responsabilidades del empresario a que dé lugar, incluidas las de la Seguridad Social, no invalidará el contrato de trabajo respecto a los derechos del trabajador extranjero, ni será obstáculo para la obtención de las prestaciones derivadas de supuestos contemplados por los convenios internacionales de protección a los trabajadores $u$ otras que pudieran corresponderles, siempre que sean compatibles con su situación. En todo caso, el trabajador que carezca de autorización de residencia y trabajo no podrá obtener prestaciones por desempleo. Salvo en los casos legalmente previstos, el reconocimiento de una prestación no modificará la situación administrativa del extranjero».
} 
engloba los casos de las personas extranjeras mayores de edad sin documentación legal por falta de residencia legal y que no se encuentran en ninguna de las situaciones anteriores.

Estamos demostrando que el criterio de la residencia legal para acceder a la protección de la salud es un criterio excluyente que obliga a la persona inmigrante a acudir a lo previsto en el art. 3.5 Ley i6/2003, que no es otra cosa que pagar por la asistencia sanitaria recibida. Aunque también le queda usar los servicios de urgencia cuando se encuentre en un caso de enfermedad grave o tenga un accidente.

La exclusión conllevará un aumento del uso de las urgencias y, por consiguiente, un mayor coste económico para el sistema sanitario. Poniéndonos en lo peor, esta medida podría provocar efectos secundarios en la población residente en situación administrativa legal pues aquellos grupos a los que se les dificulte la entrada a la atención primaria pueden contraer enfermedades que se pueden propagar. La solución de acceso a la sanidad por medio del art. 3.5 Ley i6/2003 (pago de la correspondiente cuota) puede resultar ineficaz pues este colectivo tendrá graves dificultades para asumir el coste propuesto.

Parece ser que el legislador olvida que el art. 43.I CE no vincula el derecho a la protección de la salud a la nacionalidad. Las condiciones de ejercicio del derecho a la asistencia sanitaria básica que se imponen a las personas extranjeras en situación administrativa irregular del art. 3.5 Ley i6/2003 son inviables en relación con el coste que puede suponer para estas personas suscribir un convenio especial de prestación de asistencia sanitaria ${ }^{55}$. La tendencia que se había instaurado de favorecer la extensión subjetiva de la asistencia sanitaria que condiciona la cobertura a la falta de medios de subsistencia, supone un retroceso en la construcción de la ciudadanía social ${ }^{56}$.

\section{Conclusiones y reflexiones}

Los movimientos migratorios se producen desde tiempos remotos, pues es un hecho innato al ser humano.

A pesar de las trabas legislativas que impongan los gobiernos de los distintos Estados, no se puede evitar que las personas se desplacen de una ciudad a otra, de un país a otro.

Dentro de estos procesos migratorios, la mujer ha comenzado a tener un papel protagonista, ya que en muchas ocasiones es ella la que decide emigrar en primer lugar para ayudar a mejorar la economía familiar. De este modo podemos ver que la economía es el principal motivo por el cual emigran las personas.

No podemos olvidar que la mujer es uno de los colectivos más vulnerables de la sociedad. Se considera que el ser mujer es un hándicap, pues aún estamos intentando

\footnotetext{
${ }^{55}$ El auto de 13 de diciembre de 2012 del TC destaca que «excluir a determinados colectivos de la atención sanitaria supondría poner en riesgo su salud lo que repercutiría no sólo en su estado de salud individual sino en la prevención de la propagación de determinadas enfermedades infecto contagiosas, afectando seriamente a la salud de toda la sociedad». También establece la obligación de los poderes públicos de garantizar a toda la ciudadanía el derecho a la protección de la salud.
}

${ }^{56}$ FERNÁNDEZ BERNAT, J.A., cit. págs.I3-I5. 
superar, dejar a un lado, la cultura patriarcalista y el androcentrismo, absoluto protagonista en décadas pasadas.

Para el patriarcalismo, la mujer, por el mero hecho de ser mujer, ya es alguien inferior al hombre. La mujer debe ser protegida por el hombre de los peligros que acechan. Sin él no es capaz de salir adelante, de sobrevivir.

Hasta hace poco tiempo, determinados puestos de trabajo eran negados a las mujeres, incluso se ve mal, aún en la actualidad, que la mujer quiera anteponer su carrera profesional a la faceta de ser madre y que decida, individualmente, no tener descendencia aunque la sociedad haya impuesto lo contrario.

En términos generales, la mujer inmigrante sufre discriminación por ser mujer y por ser inmigrante. Pero si a esto añadimos que se encuentra en una situación administrativa irregular, el escenario se complica más.

¿Qué sucede si a estas características añadimos la circunstancia de ser víctima de violencia de género?

La violencia de género no entiende de clases sociales, de razas, de edades... cualquier mujer, por el mero hecho de ser mujer, puede ser víctima de las agresiones por parte de un hombre que se considera con el poder suficiente para dominar, someter y abusar de la mujer al considerarla un ser inferior.

El concepto de violencia de género otorgado por nuestra LOVG es más restringido que el que aparece en los distintos textos legislativos internacionales ${ }^{57}$. Lo que sí queda absolutamente claro en los textos internacionales y nacionales es que esta clase de violencia es «la manifestación de la discriminación, la situación de desigualdad y las relaciones de poder de los hombres sobre las mujeres. Ésta es ejercida por parte de quienes sean o hayan sido sus cónyuges o de quienes estén o hayan estado ligados a ellas por relaciones similares de afectividad, aún sin convivencia».

Considero, del mismo modo que lo hace Inmaculada Montalbán Huertas, que la violencia de género hace referencia no sólo a la violencia producida en las relaciones de pareja, sino también a toda la violencia que sufren las mujeres en el ámbito laboral, en la familia, en la calle, en las instituciones, en los medios de comunicación y la violencia simbólica que continuamente pone a la mujer en un lugar subordinado. La idea de que la mujer es un ser inferior al hombre viene dada por la cultura patriarcalista que impera aún en muchas de las sociedades actuales.

\footnotetext{
${ }^{57}$ Mientras la LOVG hace referencia a la violencia que ejerce el hombre contra o sobre la mujer con la que tiene o ha tenido una relación sentimental, aún sin convivencia, incluyéndose las relaciones de noviazgo; los textos internacionales, como la IV Conferencia Mundial de Beijing, dicen que la violencia de género se produce siendo la víctima la mujer y la persona que agrede el hombre, dando igual la relación existente entre ambas. Esta plataforma considera que la violencia contra las mujeres es una «manifestación de las relaciones de poder históricamente desiguales entre hombres y mujeres, que ha conducido a la dominación masculina, a la discriminación y a impedir el pleno desarrollo de la mujer». La Convención sobre la Eliminación de todas las formas de discriminación contra la mujer (CEDAW) establece en su art. I que la violencia basada en el sexo es aquella violencia contra la mujer porque es mujer o que la afecta en forma desproporcionada, incluyendo actos que infligen daños o sufrimientos de índole física, mental o sexual, amenazas de cometer esos actos, coacción y otras formas de privar de libertad. La Declaración de la ONU sobre la eliminación de la violencia contra la mujer establece que este tipo de violencia es todo «acto de violencia que se basa en la pertenencia al sexo femenino y que tenga o pueda tener como resultado un daño o sufrimiento físico, sexual o psicológico para las mujeres».
} 
Se tiende a hablar indistintamente de violencia de género y violencia doméstica y, como dice María Luisa Maqueda Abreu, la confusión de etiquetas entre ambas contribuye a perpetuar la probada resistencia social a reconocer que el maltrato a la mujer no es una forma más de violencia, que no es algo circunstancial ni neutro, sino instrumental y útil para mantener un orden determinado de valores estructuralmente discriminatorio para las mujeres.

La violencia de género es un problema multidisciplinar. Es decir, toca varias áreas de estudio y de trabajo, desde el ámbito jurídico (abogadas/os, jueces/zas, fiscales) hasta el psicológico, el social (trabajadoras/es sociales), el de las fuerzas y cuerpos de seguridad del Estado, etc. Es por ello que considero que el trabajo a realizar para su erradicación debe ser conjunto, en equipo y no individual y como áreas separadas y estancas.

En relación a los derechos que les corresponden a las mujeres víctimas de violencia de género, el art. I7 LOVG recoge «la garantía de los derechos de las víctimas» estableciendo que «los derechos reconocidos en esta ley (LOVG) los tienen garantizados las mujeres víctimas de violencia de género con independencia de su origen, religión o cualquier otra condición o circunstancia personal o social». Se entiende que las mujeres inmigrantes víctimas de la violencia de género en situación administrativa irregular también los tienen reconocidos y garantizados, pero en la realidad, estos derechos están mermados o son violados.

Las limitaciones que sufren los derechos de las mujeres víctimas de violencia de género que son inmigrantes en situación administrativa irregular les provocan la sensación de ser ellas las delincuentes, de ser las autoras de un delito y que las víctimas son los hombres que han provocado en ellas unas heridas físicas y, sobre todo, mentales que parece ser que la justicia no es capaz de ver.

Toda persona, sin distinción de nacionalidad, raza, origen, sexo, etc. tiene reconocidos unos derechos, denominados humanos, y que son básicos y que le pertenecen por ser persona, como se establece en la Declaración Universal de los Derechos Humanos que está recogida en la Constitución Española.

Al tratarse de unos derechos reconocidos a nivel internacional y también nacional, deben ser protegidos como aparece escrito en el Preámbulo de la Constitución al establecer como uno de los objetivos del texto constitucional el de «proteger a todos los españoles y pueblos de España en el ejercicio de los derechos humanos, (...)».

El derecho a la asistencia jurídica gratuita se merma, se vulnera, se viola porque la burocracia exige que se demuestre que la persona que lo solicita se encuentra en una situación económica precaria que le impide poder pagar a otra persona de su elección para que la represente y defienda en un proceso judicial. La mujer, al carecer de cualquier tipo de documento que acredite su situación económica y, por tanto, que acredite su estancia de forma regular en España, es rápidamente excluida de la posibilidad de obtener un/a abogado/a que la asesore en el arduo periplo judicial que se le puede presentar como consecuencia de denunciar unos hechos que se encuadran dentro de la violencia de género. El trámite se inicia sí, pero se queda paralizado ante la ausencia de documentación presentada por ella. 
Esto lleva aparejada la vulneración de la posible ejecución del derecho a la jurisdicción, a un proceso sin dilaciones indebidas y a obtener una sentencia congruente, todos ellos incluidos dentro del derecho general a la tutela judicial efectiva.

El derecho a la salud es un derecho humano reconocido internacional y nacionalmente, que también está siendo violado en la actualidad cuando nos referimos a las mujeres inmigrantes en situación irregular que son víctimas de violencia de género. Ha sido vulnerado tras la última reforma realizada por el Gobierno operada por medio del Real Decreto-Legislativo I6/20I2 (de 20 de abril, de medidas urgentes para garantizar la sostenibilidad del Sistema Nacional de Salud y mejorar la calidad y seguridad de sus prestaciones),

La solución que les queda a estas personas, a estas mujeres que se hallan desamparadas y confusas, es acudir a las ONG's o a las asociaciones. Estas organizaciones ven aumentado el número de personas a las que atender, pero también ven menguados los recursos con los que hacer frente al aumento de solicitudes de ayuda y, por lo tanto, se encuentran desbordadas.

Hemos avanzado en la consecución de derechos para el ser humano, hemos avanzado tecnológicamente hablando, pertenecemos al llamado primer mundo, al mundo desarrollado; pero somos los primeros en vapulear, vilipendiar, deshonrar todos aquellos logros que nuestros antepasados han conseguido. Nuestro pecho se ensancha al considerarnos seres superiores que nos encontramos en un mejor mundo porque nuestras «leyes» recogen derechos humanos y nuestro Estado se codea con grandes países, pero en la realidad, en la práctica, los derechos únicamente están escritos en un papel y no son efectivos en el día a día de nuestra sociedad.

La mujer ha logrado grandes avances: el derecho al voto, el derecho a trabajar, a tener un salario digno, etc. Pero aún tenemos que superar muchos obstáculos en nuestra vida diaria porque la cultura del patriarcalismo y del machismo aún sigue latente en nuestra sociedad.

La mujer tiene que gritar más alto y más fuerte por sus derechos, porque éstos no sean dañados y porque sea considerada un ser igual que el hombre y con las mismas oportunidades que éstos.

Pero nosotras somos a las primeras, o de las primeras, a las que se les toca sus derechos y quedan, desafortunadamente, más discriminadas que otros colectivos.

Muchos grupos de personas consideran que la Ley I/2004 es una ley discriminatoria para los hombres. Pero yo considero que esta ley, desgraciadamente tiene que existir para dar nombre y para sacar a la luz pública una realidad que hasta ahora, estaba oculta. Desgraciadamente tienen que existir leyes cuya principal protagonista sea la mujer, para que ella no sea discriminada y sea tratada de igual modo que los hombres.

Aún tenemos mucho camino que recorrer porque los obstáculos cada vez son mayores, y la conciencia y la cultura deben variar aún en nuestra sociedad.

Debemos empezar a educar a las generaciones que vienen a que la igualdad no es sólo material, sino que la igualdad es algo palpable en el día a día de nuestra sociedad. Debemos enseñar que lo rosa no corresponde sólo a las mujeres y que lo azul no es sólo 
para los hombres, sino que éstos también pueden llorar porque es una forma de expresar los sentimientos, algo que no es malo, sino que te hace más humano. 